\title{
Accounting
}

\section{Capital structure and firm performance of non-financial listed companies: Cross-sector empirical evidences from Vietnam}

\author{
Thanh Hieu Nguyen ${ }^{a *}$ and Huu Anh Nguyena
}

\begin{tabular}{l}
$\frac{{ }^{a} \text { National Economics University, }}{\text { C H R O N I C L E }}$ \\
\hline Article history: \\
Received October 122019 \\
Received in revised format \\
November 142019 \\
Accepted November 162019 \\
Available online \\
November 162019 \\
\hline Keywords: \\
Assets \\
Debt \\
Generalized least square \\
Profitability \\
Return on asset
\end{tabular}

\section{A B S T R A C T}

\begin{abstract}
This paper examines the relationship between capital structure and profitability of non-financial companies listed on Vietnam's stock market. The panel data is extracted from financial statements of 488 listed companies between 2013 and 2018. Capital structure discussed is represented by the ratios of short-term liabilities, long-term liabilities and total liabilities to total assets, and profitability is measured by Return on Equity (ROE), Return on Assets (ROA) and Earnings per share (EPS). Firm size, growth rate, liquidity, ratio of fixed assets to total assets are control variables in the study. The Generalized Least Square (GLS) is applied to different models, including ROE, ROA and EPS Model, and tests of autocorrelation, multicollinearity and heteroskedasticity are run to confirm the relationship between capital structure and business performance. The results show that the capital structure of Vietnamese listed non-financial companies is negatively related to their performance. Taking industrial product sectors as the preference sectors, the results show that pharmaceutical and medical, the consumer goods and the public utility industries had a higher relationship between capital structure and firm's performance (via ROE, ROA, EPS) than industrial product sectors. These evidences are useful new insights to investors, business managers and governmental authorities.
\end{abstract}

\section{Introduction}

Capital structure is referred to the way that a company finances its assets by combining liabilities and equities. Business performance of an enterprise is directly affected by its capital structure decisions (Saad, 2010). If the company is financed entirely by equity, it is more proactive in funding sources and free from financial risks at a price of high average cost of capital since equity is more expensive than debt. Conversely, a firm using more debt to fund its assets could lower the average cost of capital at the cost of higher financial risks. Therefore, businesses must always seek for an optimal capital structure to minimize financial risks and reduce the average cost of capital. The linkage between capital structure and profitability has attracted a lot of debate and academic attention across scholars globally (e.g., Roden \& Lewellen, 1995; Arbabiyan \& Safari, 2009; Mahfuzah \& Raj, 2012; Logavathani \& Lingesiya, 2018), but such studies do not reach a uniform conclusion on the sign of this relationship. There are studies showing that capital structure is positively related to business results, while others believe that former is negatively related to the latter. There are empirical studies concluded that there is no significant relationship between these two factors. Therefore, this topic requires more researches with additional empirical evidences, especially from Vietnamese nonfinancial listed companies, to create insights. Despite the diverse studies in other countries such as the United States (Roden \& Lewellen, 1995), Pakistan (Amjed, 2011), Malaysia (Mahfuzah \& Raj, 2012), Sri Lanka (Prahalathan \& Ranjani, 2011; Nirajini \& Priya, 2013), Egypt (Ebaid, 2009), Iran (Nikoo, 2015), Jordan (Taani, 2013), among others, the topic has not yet been

* Corresponding author.

E-mail address: hieu39ktqd@gmail.com (T. H. Nguyen) 
systematically analyzed in Vietnam and Asian country recently transited from centralized and subsidized management to a socialist-oriented market economy. This study aims to find evidences on the relationship between capital structure and performance of Vietnamese non-financial listed companies and present recommendations to state management agencies, business managers and related parties.

The remainder of this article is structured in five sections, including Section 2: Theoretical Basis and Literature Review, Section 3: Research Hypotheses and Research Methodology, Section 4: Empirical results on the relationship between capital structure and performance of Vietnamese non-financial listed companies, Section 5: Discussion on Research Results, and Recommendations and Conclusion are given in the last section.

\section{Theoretical basis and literature review}

\subsection{Theoretical basis}

Theories related to the selection of capital structure in enterprises are diverse, namely Modigliani and Miller theory, trade-off theory, Pecking order theory, market timing theory, etc. Many research scholars have tried to find empirical evidences to support these theories over the years.

\subsubsection{Modigliani and Miller theory}

The most fundamental theory for the structure of capital is possibly the theory of Modigliani and Miller (1958) and Modigliani and Miller (1963). Assuming that corporate income tax rate is zero, Modigliani and Miller (1958) claim capital structure is irrelevant to firm's value or the firm has no way to increase its value by changing the capital structure. By including corporate income tax into the research model, Modigliani and Miller (1963) conclude the value of firms that have more debt in their capital structure is equal to the market value of firms that do not have debt in their capital structure plus what is known as the "tax shield". In summary, Modigliani and Miller show that capital structure influences the firm's market value.

\subsubsection{Trade-off theory}

In order to complete the theory of Modigliani and Miller (1963), a number of later studies have included financial distress and agency costs, for example, Kraus and Litzenberger (1973), Jensen and Meckling (1976), etc. Kraus and Litzenberger (1973) were those of the first researchers to formally address the trade-off theory by concluding that the market value of a firm with debt equal to the value of a company without debt plus the value of tax shield minus the present value of bankruptcy costs. This means that the benefits of tax shield gained from debts will be offset against losses in case of bankruptcy. In a nutshell, this theory suggests that there exists an optimal capital structure for businesses, in which the benefit of tax shield best compensates for the losses from debts, such as financial distress and agency costs.

\subsubsection{Pecking order theory}

Pecking order theory explains financing decisions of business managers. Given the need for capital, businesses put an order of priority for their funds: they first use internal capital (e.g., internal funds, retained earnings), followed by loans (e.g., debt securities), and finally, new equity. This theory was first studied by Donaldson (1961), resulting from the information asymmetry between company owners and external investors. While owners are fully aware of the firm's financial situation, external investors are poorly informed, and therefore, they are always skeptical about completeness and truthfulness of the information provided by the company owners. Therefore, companies often have to pay higher costs for external finance. The pecking order theory states that internal capital will always be preferred to loans and the use of internal funds will reduce the dependence of enterprises on external parties, increase financial autonomy and reduce the leakage of internal information.

\subsubsection{Market timing theory}

Baker and Wurgler (2002) conclude the market timing theory best explains the capital structure of enterprises and shows that the volatility of stock prices will significantly affect the capital structure. The authors deny the existence of an optimal capital structure and consider the formation of capital structure as the result of decisions that change the capital structure at the time of business valuation by market value. Roden and Lewellen (1995) are pioneers in the study of leverage and profitability relationship of businesses in the United States. Their sample included 48 American firms between 1981 and 1990 . The authors acknowledged a positive correlation between the debt ratio and profitability. Following Roden and Lewellen (1995), the relation is examined in other countries around the world. The studies are different by variables in research model, research methodologies and research results, creating a vivid picture of the relationship between capital structure and performance. Abor (2005) studied 
this relationship in companies listed on the Ghana Stock Exchange during a five-year period (1998-2002). These companies have $85 \%$ of short-term debt out of total liabilities. The author found a positive correlation between the ratio of short-term debt to total assets and profitability (measured by ROE) and a negative sign between the ratio of long-term debt to total assets and profitability.

\subsection{Literature review}

Amjed (2011) investigated listed textile companies in Pakistan to determine the relationship between profitability and leverage. Data was collected from financial statements of 100 listed textile companies listed on Pakistan's Karachi Stock Exchange from 1999 to 2004. Profitability was measured by ROE, and leverage was represented by the ratios of short-term debt to total assets, long-term debt to total assets and total debt to total assets. The results indicate that the ratio of short-term debt was significant and positively correlated with ROE, so the use of more short-term debt could escalate profits. However, the ratio of long-term debt was significant with opposite effects. Long-term debt increased costs (both direct and indirect expenses), so the higher the long-term debt, the lower the profitability. Lastly, there was no significant relationship between the ratio of total debt to total assets and ROE. ElKelish (2007) also conducted a survey on the impact of financial structure on performance of businesses in the United Arab Emirates. He collected data from the financial statements of listed food companies from 1996 to 2000 . Empirical results show that the debt to equity ratio had no impact on business performance. The study of Arbabiyan and Safari (2009) on the impact of capital structure on profitability in 100 Iranian listed companies from 2001-2007 indicated a positive correlation between either the ratio of short-term debt or the debt ratio and ROE, while the ratio of long-term debt to total assets and ROE are negatively correlated. Ebaid (2009) discussed the effects of debt ratios on firm performance, which is measured by Return on Assets (ROA), Return on Equity (ROE) and Gross Margin (GM). The research analysed data from listed companies in Egypt between 1997 and 2005. The author presented a weak negative correlation between ROA and the short-term debt ratio, as well as the debt ratio. However, the ratios of short-term debt, long-term debt and total debt to total assets was not significantly correlated with both ROE and GM. Prahalathan and Ranjani (2011) examined the capital structure choice on corporate performance of 65 listed companies on the Colombo Stock Exchange (Sri Lanka) in the period 2003-2007. They could not find a significant relationship between the ratios of short-term debt, long-term debt and total debt to total assets and profitability, which is represented by ROE and ROA.

Rehman et al. (2012) studied the relationship of leverage and profitability of textile companies in Pakistan. The authors randomly selected 17 companies in the textile industry and used the smallest mean method. Profitability was measured by ROE and leverage by the ratios of short-term debt to total assets, long-term debt to total assets and total liabilities to total assets. The results indicated a significantly positive correlation between the ratio of short-term debt to total assets and ROE, but the ratio of long-term debt to total assets and ROE were not significantly correlated. Khan (2012) studied the relationship between capital structure decisions and firm performance on engineering sector of Pakistan during the period 2003-2009. ROA, ROE, Gross Margin (GM) and Tobin's Q are measurement of firm performance. Financial leverage was measured by short-term debt to total assets, long-term debt to total assets and total debt to total assets. Applying POLS regression for four models using ROA, ROE, GM and Tobin's Q as dependent variables, while the independent variables were short-term debt to total assets, long-term debt to total assets and total debt to total assets, the author concluded the ratios of short-term debt to total assets and total debt to total assets are inversely related to ROA; the ratios of short-term debt, long-term debt and total debt to total assets were weakly related to ROE; the ratios of short-term debt and total debt to total assets were negatively related to GM, while the ratio of longterm debt to total assets was statistically positively related to GM and Tobin's Q. Mahfuzah and Raj (2012) examined 237 companies listed on the Malaysian Stock Exchange from 1995 to 2011 . ROE, ROA, Tobin's Q and EPS represented business performance, while the ratios of short-term debt, long-term debt, and total liabilities to total assets were measurements of capital structure. As shown in the study, the ratios of short-term debt and total debt to total assets were inversely related to ROE, while the ratios of long-term debt and total debt to total assets were negatively related to ROA. All three ratios of leverage were positively related to Tobin's Q.

Yogen et al. (2014) investigated the relationship between capital structure and the profitability of 11 banks operating in Kenya for the nine-year period from 2004. ROE was the financial ratio representing profitability in Kenyan banks, while the ratios of short-term debt, long-term debt, total liabilities to total assets measure capital structure. Firm size and sale growth were control variables included in the research model. The authors used OLS regression techniques and reported that short-term debt had a positive relationship with profitability, long-term debt was negatively related to ROE, and total liabilities were irrelevant. Doan and Dinh (2014) analysed data of 235 companies listed on Ho Chi Minh City Stock Exchange in Vietnam from 2009 to 2013 and used the ratios of long-term debt to equity and total liabilities to equity to measure leverage. ROE and EPS (earnings per share) were indicators of profitability. The study pointed out a negative relationship between the selected leverage ratios and business performance. Chang et al. (2014) studied the relationship between financial structure and performance of non-financial companies listed on Ho Chi Minh Stock Exchange in Vietnam from 2007 to 2011. This period covered the time before, during and after the global economic crisis, which originated from the US before hitting other countries including Vietnam. The paper 
measured profitability by ROA, ROE, and Tobin'Q (calculated by the market price of equity plus book value of liabilities divided by total assets) and MBVR (market to book value ratio). Financial structure was measured by the ratios of short-term debt, longterm debt, and total debt to total assets. Control variables were firm size, ratio of fixed assets to total assets, and corporate income tax rate. The authors employed FEM, REM and OLS regression techniques and Hausman test to select FEM model to conclude on the relationship between capital structure and performance. They indicated a negative correlation between debt (including short-term debt, long-term debt and total debt) and ROA. Firm size was statistically positively related to ROA in all forms of capital structure. A negative relation existed between the ratio of fixed assets to total assets and ROA. Tax rate was weakly significant to ROA (in both long-term debt and total debt models) and statistically insignificant in the short-term debt model. Having ROE as a measure of business results, the research reported that the ratios of short-term debt and total debt to total assets were negatively related to ROE, while long-term debt is insignificant to ROE. Firm size was positively related to $\mathrm{ROE}$ in all models of short-term debt, long-term debt and total debt. The ratio of tangible fixed assets was statistically significant and negatively related to ROE in the short-term debt model. Tax rate was statistically insignificant to ROE in all research models. Ramadan and Ramadan (2015) identified the effect of capital structure on the performance of 72 companies listed on the Amman Stock Exchange during the period between 2005 and 2013. The authors used ROA as a measure of profitability and the ratios of long-term debt to total assets and total debt to total assets as indicators of capital structure. Applying OLS regression, the authors stated that debt ratios were negatively related to performance. Well-performing firms were less dependent on credit. This result is consistent with the Pecking-order theory when companies prefer equity. Logavathani and Lingesiya (2018) investigated on the relationship between capital structure and performance of 10 commercial banks in Sri Lanka. ROA and ROE were two financial indicators used to measure profitability of banks. The ratios of short-term debt, long-term debt and total debt to total assets represent leverage. The authors applied the Fixed Effect Model and Random Effect Model to analyse data and concluded on this relationship. The results of FEM regression from ROA model and REM regression from ROE model highlighted that the ratio of total debt to total assets was closely and negatively related to ROA and ROE of commercial banks in Sri Lanka, and the ratios of short-term and long-term debt to total assets are not statistically significant related to ROA and ROE. The deposit growth was statistically significant and positively related to ROA and ROE. Bank size did not have a statistically significant relationship with ROA, ROE.

Based on the literature review, the following research gaps are pointed out:

First, the sign of leverage and profitability relationship is inconsistent in the studies. Empirical studies from different economies, at different times and different research methods bring diverse and mixed research results. Therefore, this topic needs further research to enrich the empirical evidences.

Second, the studies of this topic are not diverse and updated in Vietnam.

There are various papers on the relationship between capital structure and firm performance in a wide range of countries such as Sri Lanka (Prahalathan \& Ranjani, 2011; Nirajini \& Priya, 2013; Logavathani and Lingesiya, 2018), Pakistan (Khan, 2012), Iran (Nikoo, 2015), Jordan (Taani, 2013; Ramadan \& Ramadan, 2015), Kenya (Yogen et al., 2014; Renoh, 2015), Bangladesh (Siddik et al., 2017), Malaysia (Mahfuzah and Raj, 2012). However, there are only a few studies in Vietnam (Chang et al., 2014; Doan and Dinh, 2014), using old data sets before 2013.

Third, new methodologies are needed to fix problems in the formerly common methods.

The past empirical studies analysed panel data by FEM and REM as the most common methods. Then the Hausman test is run to check the model validity before coming to conclusions. However, a disadvantage of panel data with large numbers of observations in a short time series is heteroscedasticity (i.e., error variances are not constant), which is not easily fixed. In addition, there is a problem of endogenous variable (i.e., a two-way correlation between the explanandum and the explanans), resulting in ineffective FEM and REM estimates. Therefore, new methods such as Generalized Least Square (GLS) are necessary to address the above-mentioned phenomena and produce more reliable estimates.

\section{Research Hypotheses}

First, the ratio of total debt to total assets gives investors an overview of the financial strength and capital structure of a business and how it finances the operations. In principle, the lower this ratio is, meaning that liabilities account for a small proportion of total assets, the less financial risk the business exposes. A higher ratio reflects a riskier funding structure and a greater chance of insolvency and bankruptcy. There are different studies examining this relationship, such as Mahfuzah and Raj (2012); Doan and Dinh (2014), Logavathani and Lingesiya (2018), who concluded that the ratio of total debt to total assets is inversely 
proportional to business performance, i.e., increasing the debt ratio would result in less profitable businesses. In contrast, other studies exist, showing a positive correlation (Arbabiyan \& Safari, 2009), no correlation (Chang et al., 2014; Ebaid, 2009; Prahalathan \& Ranjani, 2011) or a weak correlation (Khan, 2012) between these factors. In the case of firms listed on Vietnam's stock market, how is profitability and leverage related? This question puts the authors to the first hypothesis.

$\mathbf{H}_{1}$ : There is a negative relationship between the ratio of total debt to total assets and performance of non-financial companies listed in Vietnam.

Second, liabilities can be categorized into short-term debts and long-term debts. Theoretically, companies using short-term debts must regularly replicate the cycle of repaying old debts and borrowing new ones. Short-term debts are sensitive to market interest rates, causing instability in the use of capital. On the other hand, interest rates of long-term debt are more stable. Abor (2005), Amjed (2011) and Arbabiyan and Safari (2009) found a positive correlation between the ratio of short-term debt to total assets and business performance and an inverse correlation between the ratio of long-term debt to total assets and business outcomes (measured by ROE). Meanwhile, Chang et al. (2014) discussed the ratio of short-term debt to total assets was negatively related to ROE while long-term debt is statistically insignificant to ROE. Prahalathan and Ranjani (2011) concluded the ratios of shortterm debt, long-term debt and total debt to total assets are insignificant to both ROE and ROA. Khan (2012) suggested the ratios of short-term debt, long-term debt and total debt to total assets are weakly related to ROE. In the context of Vietnam, in order to determine the relationship between short-term debt and/or long-term debt to business performance, the following two hypotheses are presented:

$\mathbf{H}_{2}$ : There is a negative relationship between the ratio of long-term debt to total assets and performance of non-financial listed companies in Vietnam.

$\mathbf{H}_{3}$ : There is a negative relationship between the ratio of short-term debt to total assets and performance of non-financial listed companies in Vietnam.

\section{Research Methodology}

\subsection{Data Collection}

The study used panel data collected from 488 non-financial companies listed on Stock Exchange over a six-year period from 2013 to 2018 provided by FiinGroup JSC. Research data is extracted from the audited financial statements of these companies.

\subsection{Research Models}

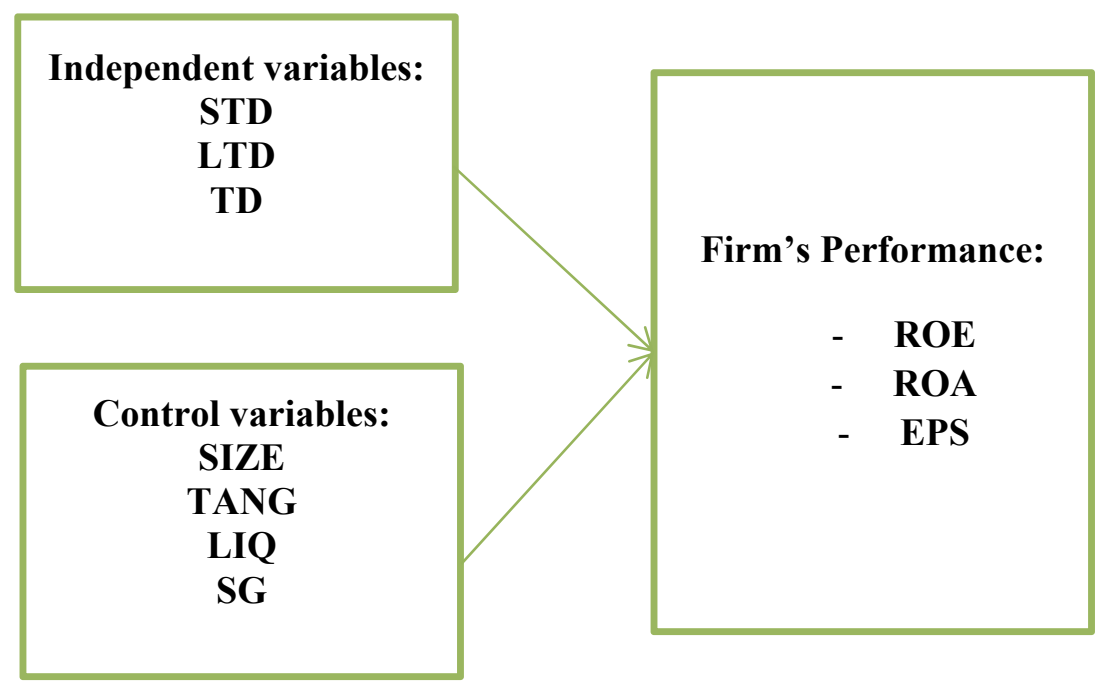

Fig. 1. Research Model

The relationship of capital structure and business performance is shown in the following three models:

- ROE Models: ROE models include 3 smaller models: STD, LTD and TD model as follow: 


$$
\begin{aligned}
& R O E_{i, t}=\alpha_{0}+\alpha_{1} S T D_{i, t}+\alpha_{2} \text { Tang }_{i, t}+\alpha_{3} S G_{i, t}+\alpha_{4} \text { Size }_{i, t}+\alpha_{5} L_{I} Q_{i, t}+{ }_{i, t} \\
& R O E_{i, t}=\beta_{0}+\beta_{1} L T D_{i, t}+\beta_{2} \text { Tang }_{i, t}+\beta_{3} S G_{i, t}+\beta_{4} \text { Size }_{i, t}+\beta_{5} L I Q_{i, t}+{ }_{i, t} \\
& R O E_{i, t}=£_{0}+£_{1} T D_{i, t}+£_{2} \text { Tang }_{i, t}+£_{3} S G_{i, t}+£_{4} \text { Size }_{i, t}+£_{5} L I Q_{i, t}+\quad{ }_{i, t}
\end{aligned}
$$

- ROA Models: ROA models include 3 smaller models: STD, LTD and TD model as follow:

$$
\begin{aligned}
& R O A_{i, t}=\alpha_{0}+\alpha_{1} S T D_{i, t}+\alpha_{2} \text { Tang }_{i, t}+\alpha_{3} S G_{i, t}+\alpha_{4} \text { Size }_{i, t}+\alpha_{5} L_{I} Q_{i, t}+{ }_{i, t} \\
& R O A_{i, t}=\beta_{0}+\beta_{1} L T D_{i, t}+\beta_{2} \text { Tang }_{i, t}+\beta_{3} S G_{i, t}+\beta_{4} \text { Size }_{i, t}+\beta_{5} L I Q_{i, t}+{ }_{i, t} \\
& R O A_{i, t}=£_{0}+£_{1} T_{i, t}+£_{2} \text { Tang }_{i, t}+£_{3} S G_{i, t}+£_{4} \text { Size }_{i, t}+£_{5} L I Q_{i, t}+\quad i, t
\end{aligned}
$$

- EPS Models: EPS models include 3 smaller models: STD, LTD and TD model as follow:

$$
\begin{aligned}
& \operatorname{EPS}_{i, t}=\alpha_{0}+\alpha_{1} \operatorname{STD}_{i, t}+\alpha_{2} \text { Tang }_{i, t}+\alpha_{3} S G_{i, t}+\alpha_{4} \text { Size }_{i, t}+\alpha_{5} \text { LIQ }_{i, t}+{ }_{i, t} \\
& E P S_{i, t}=\beta_{0}+\beta_{1} L T D_{i, t}+\beta_{2} \text { Tang }_{i, t}+\beta_{3} S G_{i, t}+\beta_{4} \text { Size }_{i, t}+\beta_{5} L I Q_{i, t}+\quad{ }_{i, t} \\
& E P S_{i, t}=£_{0}+£_{1} T_{i, t}+£_{2} \text { Tang }_{i, t}+£_{3} S G_{i, t}+£_{4} \text { Size }_{i, t}+£_{5} L I Q_{i, t}+\quad{ }_{i, t}
\end{aligned}
$$

\begin{tabular}{|c|c|c|}
\hline Variables & Variable Name & Measurement \\
\hline \multirow[t]{2}{*}{ ROE } & Return on equity & Net Income \\
\hline & & $\overline{\text { Stockholders' Equity }}$ \\
\hline \multirow[t]{2}{*}{ ROA } & Return on asset & Net Income \\
\hline & & $\overline{\text { Total Assets }}$ \\
\hline \multirow[t]{2}{*}{ EPS } & Earnings per share & Net Income - Prefered Dividend \\
\hline & & Weighted average common stock outstanding \\
\hline \multirow[t]{2}{*}{ STD } & Short-term debt to total assets & Short term Debt \\
\hline & & $\overline{\text { Total Assets }}$ \\
\hline \multirow[t]{2}{*}{ LTD } & Long term debt to total assets & Long term Debt \\
\hline & & Total Assets \\
\hline \multirow[t]{2}{*}{$\mathrm{TD}$} & Total debt to total assets & Total Debt \\
\hline & & $\overline{\text { Total Assets }}$ \\
\hline \multirow[t]{2}{*}{ Tang } & Tangibility & Fixed Assets \\
\hline & & $\overline{\text { Total Assets }}$ \\
\hline \multirow[t]{2}{*}{ SG } & Sale growth & Net Sale (t) - Net Sale (t-1) \\
\hline & & Net Sale (t) \\
\hline Size & Firm size & Ln (Total assets) \\
\hline \multirow[t]{2}{*}{ LIQ } & Liquidity & Current Asset \\
\hline & & $\overline{\text { Shortterm Debt }}$ \\
\hline
\end{tabular}

Variable names and measurements in three models are explained in Table 1.

\section{Table 1}

Measurement of variables used in research models

\subsection{Research Design}

Since the panel data covers a short period (six years) with large number of enterprises, so the Generalized Least Square (GLS) is adopted. Following the regression of these models, the required tests for multicollinearity, autocorrelation are run to confirm that the conclusions are firm, unbiased and valid. Testing rules are as follows:

Multicollinearity test: Variance Inflation Factor (VIF) is used to check multicollinearity. According to Hoang and Chu (2013), if VIF value is less than 10 , the model has no multicollinearity.

Model validity, autocorrelation and heteroskedasticity test:

Following the regression of these models, the authors checked the model validity and verify the compliance with important 
assumptions such as: no autocorrelation, constant variance or multicollinearity. The model validity is tested by examining the F-statistic value from regressions (i.e., Prob (F-statistic) $<0.1$ means a valid model). The correlation and constant variance are checked which tests the null hypothesis that all error variances are equal versus the alternative that the error variances are a multiplicative function of one or more variables. If the Prob (F-statistic) value obtained after this test is $<0.1$, the research concludes that the error variances are not equal.

\section{Results and Discussion}

\subsection{Descriptive Statistic}

Table 2

Descriptive Statistics

\begin{tabular}{|c|c|c|c|c|c|}
\hline Variables & Obs & Mean & Std. Dev. & Min & Max \\
\hline ROE & 3,416 & 0.116458 & 0.166448 & -2.6532 & 1.6075 \\
\hline ROA & 3,416 & 0.062108 & 0.083343 & -0.6246 & 0.8391 \\
\hline EPS & 3,402 & 2311.655 & 3157.768 & -10332.4 & 51411.19 \\
\hline STD & 3,415 & 0.410193 & 0.214953 & 0.001981 & 0.962629 \\
\hline LTD & 3,415 & 0.090122 & 0.134182 & 0 & 0.787283 \\
\hline $\mathrm{TD}$ & 3,415 & 0.500315 & 0.225355 & 0.001981 & 0.992909 \\
\hline SIZE & 3,415 & 27.08674 & 1.508056 & 23.33036 & 32.20036 \\
\hline TANG & 3,415 & 0.261613 & 0.2136 & 0 & 0.96975 \\
\hline SG & 3,412 & 0.26738 & 4.867771 & -1 & 244.4558 \\
\hline LIQ & 3,415 & 2.390804 & 5.741091 & 0.048017 & 229.7474 \\
\hline
\end{tabular}

The statistics (Table 2) show profitability of Vietnamese listed companies during the research period with the average ROE of $11.64 \%($ Mean $(\mathrm{ROE})=0.116458))$ and the highest ROE of $1.6 \%(\mathrm{Max}(\mathrm{ROE})=1.6075))$; average ROA of $6.2 \%(\mathrm{Mean}(\mathrm{ROA})$ $=0.062108))$ and the highest ROA of $83.91 \%(\operatorname{Max}(\mathrm{ROA})=0.8391))$; average EPS of 2,311 Vietnamese dong $($ Mean $($ EPS $)=$ 2,311)) and the highest EPS of 51,411 Vietnamese dong (Max (EPS) = 51,411)). In addition, the average value of short-term debt to total assets (STD) is 41\% (Mean (STD) = 0.410193) while the ratio of long-term debt (LTD) is only 9\% (Mean (STD) $=0.090122$ ). This implies that Vietnamese companies mainly use short term debt to finance their operations due to the difficulty in their access to long-term credit from financial institutions. Thus, the mean of total debt to total assets (TD) is about 50\% $($ Mean $($ Mean $(T D)=0.500315)$. The sale growth is positive, i.e., sale growth in the following year is $26 \%$ higher than that in the previous year (Mean $(\mathrm{SG})=0.26738)$ ). These companies are also liquidated with the average current ratio (current assets to current liabilities) at 2.390804 (Mean (LIQ) = 2.390804).

\subsection{Correlation analysis}

\section{Table 3}

Correlation coefficient

\begin{tabular}{|c|c|c|c|c|c|c|c|c|c|c|}
\hline & ROE & ROA & EPS & STD & LTD & TD & SIZE & TANG & SG & LIQ \\
\hline $\mathrm{ROE}$ & 1 & & & & & & & & & \\
\hline $\mathrm{ROA}$ & $0.810 * *$ & 1 & & & & & & & & \\
\hline EPS & $0.749 * *$ & $0.749 * *$ & 1 & & & & & & & \\
\hline STD & $-0.126^{* *}$ & $-0.336 * *$ & $-0.117^{* *}$ & 1 & & & & & & \\
\hline LTD & $-0.072 * *$ & $-0.173 * *$ & $-0.093 * *$ & $-0.235 * *$ & 1 & & & & & \\
\hline TD & $-0.164 * *$ & $-0.424 * *$ & $-0.167 * *$ & $0.815^{* *}$ & $0.371 * *$ & 1 & & & & \\
\hline SIZE & $0.069 * *$ & -0.009 & $0.136 * *$ & $0.125 * *$ & $0.385 * *$ & $0.349 * *$ & 1 & & & \\
\hline TANG & -0.014 & 0.002 & $-0.043 * *$ & $-0.353 * *$ & $0.453 * *$ & $-0.067 * *$ & $0.101 * *$ & 1 & & \\
\hline SG & $0.044 * *$ & $0.043 * *$ & 0.018 & 0.004 & -0.014 & -0.004 & -0.023 & -0.027 & 1 & \\
\hline LIQ & 0.019 & $0.110^{* *}$ & 0.022 & $-0.312 * *$ & $-0.098 * *$ & $-0.356^{* *}$ & $-0.135^{* *}$ & $-0.090 * *$ & -0.005 & 1 \\
\hline
\end{tabular}

According to the statistics obtained from the regression analysis as shown in Table 3, the relationship between the independent variables (STD, LTD and TD) and the dependent variables (ROE, ROA and EPS) is opposite (statistically significant at 5\%). The variables SG and SIZE are all positively related to ROA, ROE and EPS (statistically significant at $5 \%)$.

\subsection{Empirical results}

\subsubsection{Regression results with ROE models}

Regression results with ROE as dependent variable and STD, LTD, TD as independent variables; TANG, SG, SIZE, LIQ are control variables are summarized in Table 4, Table 5, and Table 6 respectively. Regression results of model (1) in Table 4 show that STD and ROE of all non-financial enterprises listed on Vietnam's stock market have the opposite relationship. The 
regression coefficient accepts a value of -0.152 , which is statistically significant ( $\mathrm{p}-$ value $=1 \%$ ). At the same time, the results also show that the relationship between SG, SIZE and ROE is in the same direction; TANG, LIQ and ROE are in the opposite direction, this relationship is statistically significant $(\mathrm{p}$-value $=1 \%)$.

Table 4

Relationship between capital structure (STD) and ROE (all companies)

\begin{tabular}{|c|c|}
\hline Variables & GLS Results of STD Model \\
\hline STD & $-0.152 * * *$ \\
\hline TANG & $-0.0622 * * *$ \\
\hline SG & $0.000809 * * *$ \\
\hline SIZE & $0.00224 * *$ \\
\hline LIQ & $-0.000422 *$ \\
\hline Constant & $0.0762 * * *$ \\
\hline Observations & 3,412 \\
\hline Number of i & 488 \\
\hline
\end{tabular}

The results of regression model (2) in Table 5 show that LTD and ROE of all non-financial enterprises listed on Vietnam's stock market have the opposite relationship. The regression coefficient is -0.145 , this relationship is statistically significant ( $\mathrm{p}-\mathrm{value}$ $=1 \%$ ). At the same time, the regression results also show that the relationship between TANG, SG, SIZE and LIQ and ROE is the same direction (shown in the regression coefficients obtained are positive, receiving the corresponding values of 0.0299 , $0.000855,0.00455,0.00124$, this relationship is statistically significant $(\mathrm{p}-$ value $=1 \%$ ).

\section{Table 5}

Relationship between capital structure (LTD) and ROE (all companies)

\begin{tabular}{lc}
\hline Variables & GLS Results of LTD Model \\
\hline LTD & $-0.145^{* * *}$ \\
TANG & $0.0299^{* * *}$ \\
SG & $0.000855^{* * *}$ \\
SIZE & $0.00455^{* * *}$ \\
LIQ & $0.00124 * * *$ \\
Constant & $-0.0660 * *$ \\
Observations & 3,412 \\
Number of $\mathrm{i}$ & 488 \\
\hline
\end{tabular}

The regression results of model (3) presented in Table 6 show that TD and ROE of all non-financial enterprises listed on Vietnam's stock market are negatively related. The regression coefficient is -0.183 , this relationship is statistically significant $(\mathrm{p}-$ value $=1 \%$ ). At the same time, the regression results also show that the relationship between SG, SIZE and ROE is the same direction (shown in the regression coefficients obtained are positive, receiving the corresponding values of 0.000813 ; 0.00880, TANG, LIQ) and ROE is the opposite, this relationship is statistically significant (p-value $=1 \%$ )

Table 6

Relationship between capital structure (TD) and ROE (all companies)

\begin{tabular}{lc}
\hline Variables & GLS Results of TD Model \\
\hline TD & $-0.183^{* * *}$ \\
TANG & $-0.0256^{* * *}$ \\
SG & $0.000813^{* * *}$ \\
SIZE & $0.00880^{* * *}$ \\
LIQ & $-0.000815^{* * *}$ \\
Constant & $-0.0766^{* * *}$ \\
Observations & 3,412 \\
Number of $i$ & 488 \\
\hline & Note: $(*),(* *),(* * *)$ represent for the significant level at $1 \%, 5 \%$ và $10 \%$, respectively
\end{tabular}

\subsubsection{Regression results with ROA models}

The results of GLS model scaling for model (4) for all non-financial companies listed on the stock market in Table 7 show that all three components of capital structure are STD, LTD, TD. have negative effects on ROA performance of enterprises (negative beta and p-value is less than 0.05). Specifically: 
The regression results of model (4) in Table 7 show that the relationship between STD and ROA is in the opposite direction (the regression coefficient receives negative values and is - 0.133), this relationship is statistically significant ( $\mathrm{p}$ - value $=1 \%$ ). Besides, the relationship between TANG and LIQ with ROA is opposite, the relationship between SG and SIZE with ROA is the same direction, this relationship is statistically significant $(\mathrm{p}$-value $=1 \%)$

Table 7

Relationship between capital structure (STD) and ROA (all companies)

\begin{tabular}{lc}
\hline Variables & GLS Results of STD Model \\
\hline STD & $-0.133^{* * *}$ \\
TANG & $-0.0795^{* * *}$ \\
SG & $0.00166^{* * *}$ \\
SIZE & $0.00902^{* * *}$ \\
LIQ & $-0.00105^{* *}$ \\
Constant & -0.0583 \\
Observations & 3,412 \\
Number of $i$ & 488 \\
\hline & Note: $(*),(* *),(* * *)$ represent for the significant level at $1 \%, 5 \%$ và $10 \%$, respectively
\end{tabular}

The regression results of model (5) shown in Table 8 show that the relationship between LTD and ROA is in the opposite direction (the regression coefficient receives negative values is -0.145 ), this relationship is statistically significant ( $\mathrm{p}$-value $=$ $1 \%)$. Besides, the relationship between SG and SIZE with ROA is the same direction, this relationship is statistically significant $(\mathrm{p}$-value $=1 \%)$.

\section{Table 8}

Relationship between capital structure (LTD) and ROA (all companies)

\begin{tabular}{lc}
\hline Variables & GLS Results of LTD Model \\
\hline LTD & $-0.145^{* * *}$ \\
TANG & 0.00592 \\
SG & $0.00170^{* * *}$ \\
SIZE & $0.0116^{* * *}$ \\
LIQ & 0.000408 \\
Constant & $-0.198 * * *$ \\
Observations & 3,412 \\
Number of $i$ & 488 \\
\hline & Note: $(*),(* *),(* *))$ represent for the significant level at $1 \%, 5 \%$ và $10 \%$, respectively \\
& (Source: Data processing results of authors)
\end{tabular}

The regression results of model (6) shown in Table 9 show that the relationship between TD and ROA is in the opposite direction (the regression coefficient receives a value of -0.166), and this relationship is statistically significant ( $\mathrm{p}$-value $=1 \%$ ). At the same time, the regression results also show that the relationship between SIZE and SG with ROA is in the same direction, TANG and LIQ and ROA are in the opposite direction.

Table 9

Relationship between capital structure (TD) and ROA (all companies)

\begin{tabular}{lc}
\hline Variables & GLS Results of TD Model \\
\hline TD & $-0.166^{* * *}$ \\
TANG & $-0.0479^{* * *}$ \\
SG & $0.00166^{* * *}$ \\
SIZE & $0.0150^{* * *}$ \\
LIQ & $-0.00146^{* * *}$ \\
Constant & $-0.196^{* * *}$ \\
Observations & 3,412 \\
Number of $i$ & 488 \\
\hline & Note: $(*),(* *),(* * *)$ represent for the significant level at $1 \%, 5 \%$ và $10 \%$, respectively \\
& (Source: Data processing results of authors)
\end{tabular}

\subsubsection{Regression results with EPS}

The regression results of model (7) are presented in Table 10 and show that the relationship between STD and EPS is in the opposite direction. TANG is negatively related to EPS and SIZE is positively related to EPS. These relationships are statistically significant ( $\mathrm{p}$-value $=1 \%$ ). In addition, no statistically significant relationship was found between SG and LIQ and EPS. 
Table 10

Relationship between capital structure (STD) and EPS (all companies)

\begin{tabular}{lc}
\hline Variables & GLS Results of STD Model \\
\hline STD & $-2,852^{* * *}$ \\
TANG & $-1,916^{* * *}$ \\
SG & 15.09 \\
SIZE & $339.4^{* * *}$ \\
LIQ & -14.28 \\
Constant & $-8,813^{* * *}$ \\
Observations & 3,398 \\
Number of $\mathrm{i}$ & 486 \\
\hline Note: $(*),(* *),(* *)$ represent for the significant level at $1 \%, 5 \%$ và $10 \%$, respectively &
\end{tabular}

(Source: Data processing results of authors)

The regression results of model (8) shown in Table 11 show that the relationship between LTD and EPS for all businesses is in the opposite direction (the regression coefficient has a value of -3,761). Also, the relationship between SIZE, LIQ and EPS is in the same direction.

Table 11

Relationship between capital structure (LTD) and EPS (all companies)

Variables

LTD

TANG

SG

SIZE

LIQ

Constant

Observations

Number of $i$

Note: $(*),\left({ }^{* *}\right),(* * *)$ represent for the significant level at $1 \%, 5 \%$ và $10 \%$, respectively

\section{GLS Results of LTD Model}

$-3,761 * * *$

103.3

16.01

$418.1^{* * *}$

$21.56^{* *}$

$-8,813^{* * *}$

3,398

486

(Source: Data processing results of authors)

The model regression results (9) shown in Table 12 show that the relationship between TD and EPS for all businesses is opposite (the regression coefficient is worth $-3,787$ ), and significant statistics ( $\mathrm{p}$-value $=1 \%$ ). At the same time, the relationship between SIZE and EPS is the same direction, the relationship between TANG and LIQ is opposite.

\section{Table 12}

Relationship between capital structure (TD) and EPS (all companies)

\begin{tabular}{lc}
\hline Variables & GLS Results of TD Model \\
\hline TD & $-3,787^{* * *}$ \\
TANG & $-1,266^{* * *}$ \\
SG & 15.11 \\
SIZE & $478.5^{* * *}$ \\
LIQ & $-27.43^{* *}$ \\
Constant & $-8,300^{* * *}$ \\
Observations & 3,398 \\
Number of $\mathrm{i}$ & 486 \\
\hline Note: $(*),(* *),(* *)$ represent for the significant level at $1 \%, 5 \%$ và $10 \%$, respectively & (Source: Data processing results of authors)
\end{tabular}

\section{Discussion}

Research results show that all three research hypotheses have been accepted. Analysis the effect of capital structure on profitability is given as follows:

\subsection{Discussion of the research results of ROE models}

The research results show that the relationship between capital structure and ROE for all non-financial enterprises listed on Vietnam's stock market is opposite. The regression coefficient obtained from the GLS regression is negative and statistically significant ( $p$-value $=1 \%$ ). This result supports the research result of Abor (2005), Chang et al. (2014) but did not support the research results with Prahalathan and Ranjani (2011) because Prahalathan and Ranjani (2011) could not find a significant relationship between the ratios of short-term debt, long-term debt and total debt to total assets and profitability, which is 
represented by ROE and ROA. Chang et al. (2014) having ROE as a measure of business results, the research reported that the ratios of short-term debt and total debt to total assets were negatively related to ROE. This result is also partly shared with the results of Rehman et al. (2012). The results of Rehman et al. (2012), indicated a significant positive correlation between the ratio of short-term debt to total assets and ROE, but the ratio of long-term debt to total assets and ROE are not significant correlated. Particularly, there are differences in the sectors about effects of capital structure to ROE as shown in Table 13. Specifically: Information technology, oil and gas and materials industries have lower ROE than industrial products industry (negative beta such as $-0.0195,-0.0306$ and -0.00839 ). In particular, oil and gas industry have lower ROE than information technology and materials industry (beta value: -0.0306 ; $-0.0214 ;-0.00839$ equivalent); IT industry has a lower ROE than materials. Utilities and consumer goods have a higher ROE than industrial products industry (beta value $=0.0163$ ); public utility sector has a higher ROE than consumer goods (beta value: $0.0163 ; 0.00906$ equivalent).

Table 13

Comparison of correlation coefficient between capital structure and ROE (industrial products sectors as standard)

\begin{tabular}{lccc}
\hline Industry & STD & LTD & TD \\
\hline Information technology industry & $-0.0195^{* * *}$ & $-0.0137^{*}$ & $-0.0214^{* * *}$ \\
Pharmaceutical and medical industry & $0.0177^{* * *}$ & $0.0229^{* * *}$ & $0.00599^{*}$ \\
Oil \& gas industry & -0.0182 & -0.0142 & $-0.0306^{* *}$ \\
Consumer service industry & 0.00419 & $0.0186^{* * *}$ & -0.00109 \\
Consumer goods industry & $0.0214^{* * *}$ & $0.0171^{* * *}$ & $0.00906^{* *}$ \\
Materials industry & -0.00413 & -0.00140 & $-0.00839^{* *}$ \\
Public utility industry & $0.0207^{* * *}$ & $0.0360^{* * *}$ & $0.0163^{* * *}$ \\
\hline
\end{tabular}

Note: $(*),(* *),(* * *)$ represent for the significant level at $1 \%, 5 \%$ và $10 \%$, respectively

\subsection{Discussion of the research results of ROA models}

The research results show that the relationship between capital structure and ROA for all non-financial enterprises listed on Vietnam's stock market is opposite. The regression coefficient obtained from the GLS regression is negative, statistically significant (p-value $=1 \%$ ). This result supports the results of Ebaid (2009), Doan and Dinh (2014), Chang et al. (2014), Logavathani and Lingesiya (2018). Chang et al. (2014) indicated a negative correlation between debt (including short-term debt, long-term debt and total debt) and ROA. According to Logavathani and Lingesiya (2018), the results of FEM regression from ROA model and REM regression from ROE model highlighted that the ratio of total debt to total assets is closely and negatively related to ROA and ROE of commercial banks in Sri Lanka. In particular, the industry comparison of effects of capital structure to ROA among sectors in Table 14 shows that information technology has a lower ROA than industrial products industry (negative beta $=-0.0300$, industrial products sector is referenced with the rest of industries). Consumer goods, medical pharmaceuticals and public utilities have a higher ROA than industrial products industry (beta value $=0.0234,0.0234$ and 0.0351 equivalent). In particular, because the public utility beta is larger than the consumer goods beta, the public utility ROA tends to be higher than the consumer goods industry. The pharmaceutical industry has a lower ROA than consumer goods.

\section{Table 14}

Comparison of correlation coefficient between capital structure and ROA (industrial products sectors as standard)

\begin{tabular}{lccc}
\hline Industry & STD & LTD & TD \\
Information technology industry & $-0.0282^{*}$ & -0.0231 & $-0.0300^{* *}$ \\
Pharmaceutical and medical industry & $0.0242^{*}$ & $0.0278^{*}$ & $0.0132^{*}$ \\
Oil \& gas industry & -0.0147 & -0.0121 & -0.0263 \\
Consumer service industry & 0.00296 & 0.0154 & -0.00231 \\
Consumer goods industry & $0.0348^{* * *}$ & $0.0299^{* * *}$ & $0.0234^{* * *}$ \\
Materials industry & -0.00325 & -0.00116 & -0.00727 \\
Public utility industry & $0.0396^{* * *}$ & $0.0530^{* * *}$ & $0.0351^{* * *}$ \\
\hline
\end{tabular}

Note: $(*),(* *),(* * *)$ represent for the significant level at $1 \%, 5 \%$ và $10 \%$, respectively

(Source: Data processing results of authors)

\subsection{Discussion of the research results of EPS models}

The research results show that the relationship between capital structure and EPS for all non-financial enterprises listed on Vietnam's stock market is the opposite. The regression coefficient obtained from the GLS regression is negative, statistically significant (p-value $=1 \%$ ). This research is in agreement with the results of Mahfuzah and Raj (2012), Doan and Dinh (2014). EPS (earnings per share) are indicators of profitability in study of Doan and Dinh (2014). The study pointed out a negative 
relationship between the selected leverage ratios and business performance. The study of Mahfuzah and Raj (2012) indicated that firm performance, which is measured by return on asset (ROA), return on Equity (ROE) and earning per share (EPS) have negative relationship with short term debt (STD), long term debt (LTD), total debt (TD) as independent variable. In particular, about effects of capital structure to EPS among sectors as illustrated in Table 15, the information technology industry has lower EPS than the material industry and these two industries have lower EPS than the industrial products industry (beta value = 717.8 and -536.6 equivalent). The medical pharmaceutical industry has higher EPS than consumer goods industry and industrial products industry (beta value $=608.8$ and 442.1 equivalent for pharmaceutical and medical industry and consumer goods industry).

\section{Table 15}

Comparison of correlation coefficient between capital structure and EPS (industrial products sectors as standard)

\begin{tabular}{|c|c|c|c|}
\hline Industry & STD & LTD & TD \\
\hline Information technology industry & $-667.0 * *$ & $-558.9 * *$ & $-717.8 * * *$ \\
\hline Pharmaceutical and medical industry & $873.5 * * *$ & $915.8 * * *$ & $608.8 * *$ \\
\hline Oil \& gas industry & -705.9 & -691.3 & -982.4 \\
\hline Consumer service industry & -182.2 & 65.47 & -317.7 \\
\hline Consumer goods industry & $713.9 * * *$ & $561.6 * * *$ & $442.1 * * *$ \\
\hline Materials industry & $-441.8 * * *$ & $-410.5 * *$ & $-536.6 * * *$ \\
\hline Public utility industry & -178.4 & 98.39 & -297.9 \\
\hline
\end{tabular}

Note: $(*),(* *),(* * *)$ represent for the significant level at $1 \%, 5 \%$ và $10 \%$, respectively

Source: Data processing results of authors

\section{Conclusion and recommendations}

\subsection{Conclusion}

This article has provided evidence that the capital structure of an enterprise has an impact on the business performance of nonfinancial enterprises listed on Vietnam's stock market. The research results complement previous studies with detailed information for each economic sector. Based on the results of this research, the author has proposed some recommendations to business managers, investors and state management agencies in making decisions.

\subsection{Recommendations}

\section{Firstly, for investors}

The research results show that the capital structure, in particular, the ratio of debt to total assets is closely related and statistically significant with the profitability of the companies (via ROA, ROE, EPS rates). In general, businesses with high debt-to-assets ratio will have an opposite effect on their profitability. Considering each economic sector, the effect of capital structure on ROE, ROA and EPS is different. Consumer goods, health care, and utilities have a higher relationship between capital structure and ROE than industrial product sectors; The information technology industry has a lower relation between capital structure and ROE than industrial product sectors. Moreover, the Pharmaceutical and medical industry, the consumer goods industry, and the public utility industry have a higher relationship between capital structure and ROE than industrial product sectors; The Information Technology industry has a lower relationship between capital structure and ROE than industrial product sectors. In addition, Pharmaceutical and medical industry, Consumer goods industry have a higher relationship between capital structure and EPS than industrial product sectors; Information technology industry has lower relationship between capital structure and EPS than industrial product sectors and raw material industry has lower capital structure and EPS than industrial product sectors. Therefore, this is useful information to help investors make appropriate investment decisions.

\section{Secondly, for business managers}

The experimental results of this article show that increasing the ratio of liabilities to total assets will make the business performance of the company (via ROE, ROA, EPS) decrease. At the same time, the revenue growth rate (SG) has a good effect on business performance. Therefore, business managers need to take appropriate measures to use debt, help increase sales but still ensure increased business performance.

\section{Thirdly, for the state management agencies}

The empirical results of this article show that company size (SIZE) is positively related to the company's business performance. The more companies scale up, the higher their performance (via ROE, ROA, EPS) will be. When companies need to borrow 
capital to expand the size of the company, the state management agencies need to create favorable conditions for businesses to access capital. The State should consider policies on interest rates at a reasonable level so that businesses can both receive capital and bring business efficiency.

\section{References}

Abor, J. (2005). The effect of capital structure on profitability: an empirical ananlysis of listed firms in Ghana. Journal of Rick Finance, 6(5), 438-447.

Amjed, S. (2011, June). Impact of financial structure on firm's Performance: A study of Pakistan's Chemical Sector. In Society of Interdisciplinary Business Research (SIBR) 2011 Conference on Interdisciplinary Business Research. 454-476.

Arbabiyan, A. A., \& Safari, M. (2009). The effects of capital structure and profitability in the listed firms in Tehran Stock Exchange. Journal of Management Perspective, 33(12), 159-175.

Baker, M., \& Wurgler, J. (2002). Market timing and capital structure. The Journal of Finance, 57(1), 1-32.

Chang, F. M., Wang, Y., Lee, N. R., \& La, D. T. (2014). Capital structure decisions and firm performance of Vietnamese soes. Asian Economic and Financial Review, 4(11), 1545-1563.

Doan, T.D., \& Dinh, T.H. (2014). Capital Structure and profitability of list companies in HoChiMinh City. Economics \& Development Journal. 2014 (Special issue in December), 30 - 37.

Donaldson. G. (1961). Corporate debt capacity: a study of corporate debt policy and the determination of corporate debt capacity. Boston, Division of Research, Graduate School of Business Administration, Harvard University.

Ebaid, I.E. (2009). The impact of capital - structure choice on firm performance empirical evidence from Egypt. The Journal of Rick Finance, 10(50), 477-487.

ElKelish, W.W. (2007). Financial structure and firm value: empirical evidence from the United Arab Emirates. International Journal of Business Research, 7, 69-76.

Hoang, T., \& Chu, N.M.N. (2013). Statistics applied in socio-economic research. Statistical Publishing House, Hanoi

Jensen, M.C., \& Meckling, W.H. (1976). Theory of the firm: Managerial behavior, agency costs and ownership structure. Journal of Financial Economics, 3(4), 305-360

Khan, A.G. (2012). The relationship of capital structure decisions with firm performance: A study of the engineering sector of Pakistan. International Journal of Accounting and Financial Reporting, 2(1), 245-262.

Kraus, A., \& Litzenberger, R. (1973). A state-preference model of optimal financial leverage. The Journal of Finance, 28(4), 911-922.

Logavathani, S., \& Lingesiya, K. (2018). Capital structure and financial performance: A study on commercial banks in Sri Lanka. Asian Economic and Financial Review, Asian Economic and Social Society, 8(5), 586-598

Mahfuzah, S., \& Raj, Y. (2012). Capital structure and firm performance: evidence from Malaysian listed companies. ProcediaSocial and Behavioral Sciences, 65, 156-166.

Modigliani, F., \& Miller, M.H. (1958). The cost of capital, corporation finance and the theory of investment. American Economic Review, 4(3), 261-297.

Modigliani, F., \& Miller, M.H. (1963). Corporate income taxes and the cost of capital: A correction. American Economic Review, 53, 433-443.

Nikoo, S.F. (2015). Impact of capital structure on banking performance: Evidence from Tehran stock exchange. International Research Journal of Applied and Basic Sciences, 9(6), 923-927.

Nirajini, A., \& Priya, K.B. (2013). Impact of capital structure on financial performance of the listed trading companies in Sri Lanka. International Journal of Scientific and Research publications, 3(5), 35-43.

Prahalathan, B., \& Ranjani, R.P.C. (2011). The impact of capital structure-choice on firm performance: Empirical investigation of listed companies in Colombo stock exchange, Sri Lanka. Int. J. Res. Commerce Manage. 2: 12-16. Available at: http://journal.tishreen.edu.sy/index.php/econlaw/article/download/4271/4048

Ramadan, Z.S., \& Ramadan, I.Z. (2015). Capital structure and firm's performance of Jordanian manufacturing sector. International Journal of Economics and Finance, 7(6), 279-284.

Rehman, W., Fatima, G., \& Ahmad, M. (2012). Impact of debt structure on profitability in textile industry of Pakistan. Wali ur Rehman, Goher Fatima, Dr. Mehboob Ahmad, Impact Of Debt Structure On Profitability In Textile Industry Of Pakistan. International Journal of Economic Research, 3(2). 61-70.

Renoh, C., \& Ntoiti, J. (2015). Effect of capital structure on financial performance of listed commercial banks in Kenya: A case study of Kenya commercial banks limited. Strategic, Business \& Change Journal of Management, 2(72), 750-781.

Roden, D., \& Lewellen, W. (1995). Corporate capital structure decisions: Evidence from leveraged buyouts. Financial Management, 24(2), 76-87.

Saad, N. M. (2010). Corporate Governance Compliance and the Effects to Capital Structure. International Journal of Economics and Financial, 2(1), 105-114

Siddik, N.A., Kabiraj, S. \& Joghee, S. (2017). Impact of capital structure on performance of banks in a developing economy: Evidence from Bangladesh. International Journal of Financial Studies, 5(2), 13. 
Taani, K. (2013). The relationship between capital structure and firm performance: Evidence from Jordan. Global Advanced Research Journal of Management and Business Studies, 2(11), 542-546.

Yogen, C., Cheruiyot, J., Sang, J., \& Cheruiyot, P.K. (2014). The effect of capital structure on firm's profitability: Evidence from Kenya's banking sector. Research Journal of Finance \& Accounting, 5(9), 152-159.

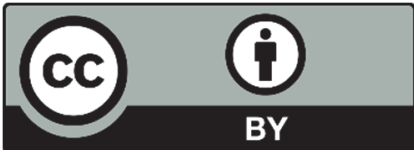

(C) 2019 by the authors; licensee Growing Science, Canada. This is an open access article distributed under the terms and conditions of the Creative Commons Attribution (CC-BY) license (http://creativecommons.org/licenses/by/4.0/). 